\title{
The effects of sodium hypochlorite against selected drinking water-isolated bacteria in planktonic and sessile states
}

\author{
I.B. Gomes ${ }^{\text {a }}$, M. Simões ${ }^{\text {a }}$, L.C. Simões ${ }^{\text {b,* }}$ \\ ${ }^{a}$ LEPABE, Department of Chemical Engineering, Faculty of Engineering, University of Porto, Rua Dr. Roberto Frias, s/n, 4200-465 Porto, Portugal \\ ${ }^{\mathrm{b}}$ CEB - Centre of Biological Engineering, University of Minho, Campus de Gualtar, 4710-057 Braga, Portugal
}

\section{H I G H L I G H T S}

- A. calcoaceticus was more susceptible to the action of $\mathrm{NaOCl}$ than $\mathrm{S}$. maltophilia.

- Biofilm removal and killing are distinct phenomena.

- High biofilm killing rates were achieved with $\mathrm{NaOCl}$ at residual concentrations.

- High concentrations of $\mathrm{NaOCl}$ cause reduced biofilm removal.

- Complementary methods to $\mathrm{NaOCl}$ are required for drinking water disinfection.
G R A P H I C A L A B S T R A C T

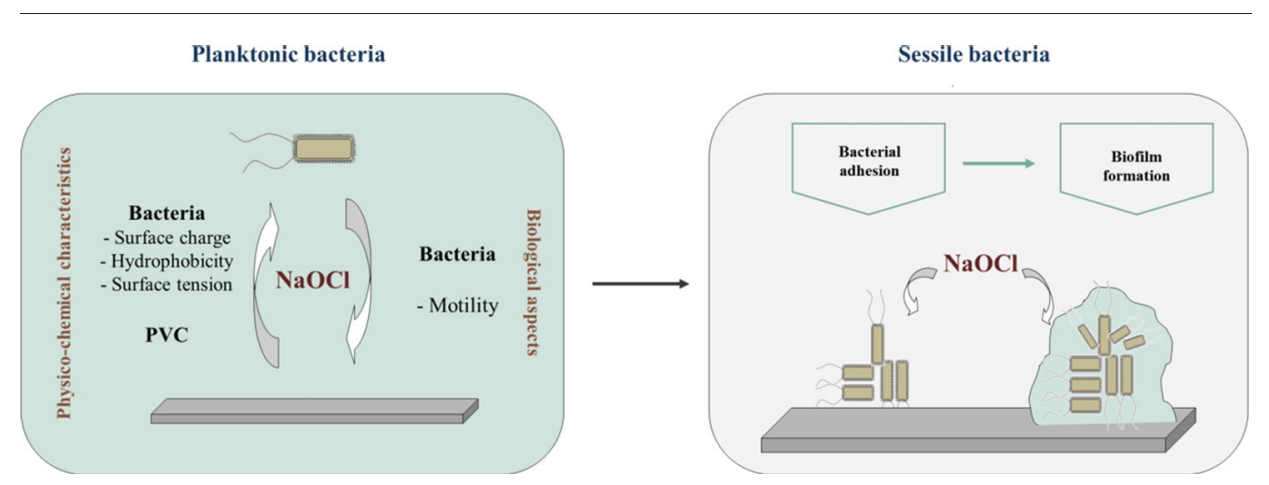

\section{A R T I C L E I N F O}

\section{Article history:}

Received 8 March 2016

Received in revised form 16 April 2016

Accepted 17 April 2016

Available online xxxx

Editor: D. Barcelo

\section{Keywords:}

Acinetobacter calcoaceticus

Adhesion

Biofilm

Motility

Physicochemical properties

Stenotrophomonas maltophilia

\begin{abstract}
A B S T R A C T
Chlorine is the most commonly used agent for general disinfection, particularly for microbial growth control in drinking water distribution systems. The goals of this study were to understand the effects of chlorine, as sodium hypochlorite $(\mathrm{NaOCl})$, on bacterial membrane physicochemical properties (surface charge, surface tension and hydrophobicity) and on motility of two emerging pathogens isolated from drinking water, Acinetobacter calcoaceticus and Stenotrophomonas maltophilia. The effects of $\mathrm{NaOCl}$ on the control of single and dual-species monolayer adhered bacteria ( $2 \mathrm{~h}$ incubation) and biofilms ( $24 \mathrm{~h}$ incubation) was also assessed. $\mathrm{NaOCl}$ caused significant changes on the surface hydrophobicity and motility of A. calcoaceticus, but not of S. maltophilia. Planktonic and sessile $S$. maltophilia were significantly more resistant to $\mathrm{NaOCl}$ than $A$. calcoaceticus. Monolayer adhered co-cultures of A. calcoaceticus-S. maltophilia were more resilient than the single species. Oppositely, dual species biofilms were more susceptible to $\mathrm{NaOCl}$ than their single species counterparts. In general, biofilm removal and killing demonstrated to be distinct phenomena: total bacterial viability reduction was achieved even if $\mathrm{NaOCl}$ at the higher concentrations had a reduced removal efficacy, allowing biofilm reseed. In conclusion, understanding the antimicrobial susceptibility of microorganisms to $\mathrm{NaOCl}$ can contribute to the design of effective biofilm control strategies targeting key microorganisms, such as S. maltophilia, and guarantying safe and high-quality drinking water. Moreover, the results reinforce that biofilms should be regarded as chronic contaminants of drinking water distribution systems and accurate methods are needed to quantify their presence as well as strategies complementary/alternative to $\mathrm{NaOCl}$ are required to effectively control the microbiological quality of drinking water.
\end{abstract}

(c) 2016 Elsevier B.V. All rights reserved.

\footnotetext{
* Corresponding author at: Centro de Engenharia Biológica, Universidade do Minho, Braga, Portugal.

E-mail addresses: up200808015@fe.up.pt (I.B. Gomes), mvs@fe.up.pt (M. Simões), luciachaves@deb.uminho.pt (L.C. Simões).
} 


\section{Introduction}

The development of a biofilm occurs in a sequential process that includes transport of microorganisms to a surface, initial (reversible and irreversible) adhesion, cell-cell communication, microcolony formation, production of extracellular polymeric substances (EPS) and biofilm maturation, with a balanced growth and dispersal (Doyle, 2000). Drinking water distribution systems (DWDS) are known to harbor biofilms, even in the continuous presence of a disinfectant. These biofilms can be a reservoir of pathogens (Li et al., 2016; Sun et al., 2014) and are a source of planktonic bacteria, which will remain present when the water is delivered through a consumer's tap (Simões and Simões, 2013). The presence of biofilms in DWDS can cause chronic drinking water (DW) contamination, reduce the esthetic quality and microbiological safety of potable water and increase the corrosion rate of pipes (Niquette et al., 2000; Percival and Walker, 1999; Simões et al., 2006; Tsai, 2005). Therefore, biofilm control is important for technical, esthetic, regulatory, and public health reasons.

Adhesion and consequent biofilm formation gives several advantages to bacteria, particularly the protection against antimicrobial agents and adverse environmental conditions. Therefore, microbial control becomes more difficult when microorganisms are embedded in biofilms (Garrett et al., 2008). Diverse strategies to control microbial adhesion and biofilm formation in DWDS were reported (Simões and Simões, 2013). The most commonly used consists on chemical disinfection, particularly with chlorine (Simões and Simões, 2013). Currently, according to the World Health Organization (WHO) the residual concentration of free chlorine leaving the treatment plant should be $<1.0 \mathrm{mg} / \mathrm{L}$ and closer to $0.5 \mathrm{mg} / \mathrm{L}$ (WHO, 2011). However, the effects of chlorine on biofilm control and its mode of antimicrobial action is still poorly understood.

The use of a material that did not encourage bacterial adhesion is also of utmost importance to control the presence of biofilms in DWDS. In recent years plastic pipes have been applied in DWDS. These plastic materials have advantageous characteristics when compared to metallic and asbestos-cement pipes, particularly its low cost, the simple installation, its external and internal resistance to corrosion and its smooth surface which facilitate the removal of deposits (Rożej et al., 2015; Safe Drinking Water Committee, Board on Toxicology and Environment Health Hazards, National Research Council, 1982). Moreover, several studies demonstrated that metallic and cement-based pipes favored bacterial attachment compared to plastic pipes (Kerr et al., 1998; Niquette et al., 2000). Iron pipes can support 10-45 times more biomass than those plastic, while cement-based materials can harbor 2.6 times more biomass than polyvinyl chloride (PVC) (Niquette et al., 2000). Rożej et al. (2015) compared biofilm formation on different plastic pipes (PVC, silane cross-linked polyethylene-PEX, and high-density polyethylene-HDPE) and demonstrated that the number of bacteria was significantly lower in biofilms formed on PVC than those formed on PEX or HDPE pipes. In this study PVC was selected as substratum for bacterial adhesion due to its broad use in DWDS. For instance, it was reported in 1982 that $80 \%$ of the plastic pipes used in DWDS at USA were made of PVC (Safe Drinking Water Committee, Board on Toxicology and Environment Health Hazards, National Research Council, 1982). Two bacteria isolated from DW, Acinetobacter calcoaceticus and Stenotrophomonas maltophilia, were used due to their increased relevance as opportunistic microorganisms (Gales et al., 2001). These bacteria were already associated with nosocomial infections related to the hospital water supply (Cervia et al., 2008; Talon et al., 1994; Weber et al., 1999). A. calcoaceticus is usually present on skin and can act as an opportunistic pathogen with highly variable degree of virulence, depending on a pre-existing break in the normal body defenses (Pal and Kale, 1981). Acinetobacter spp. are commonly found in water and are associated with nosocomial infections (Narciso-da-Rocha et al., 2013). In 1996, this species was confirmed as the responsible agent for the death of infants in maternity hospitals in Brazil (Penna et al., 2001). S. maltophilia is commonly associated with respiratory infections in humans. The treatment of
S. maltophilia infections is problematic since it is considered an emerging multidrug resistant organism (Brooke, 2012; Denton and Kerr, 1998). Vincenti et al. (2014) isolated S. maltophilia from hospital tap water and $56.3-100 \%$ of the isolates were highly resistant to the 14 tested antibiotics ( 5 beta-lactams, 2 carbapenems, 3 aminoglycosides, ciprofloxacin, colistin, fosfomycin and trimethoprim-sulfamethoxazole). These authors considered S. maltophilia potentially more dangerous than other waterborne pathogens commonly described in literature.

The aim of this study was to evaluate the effects of chlorine, as sodium hypochlorite $(\mathrm{NaOCl})$, on the control of bacterial adhesion and biofilms on PVC and to understand how this biocide can act on bacterial surface physicochemical properties, charge and motility.

\section{Material and methods}

\subsection{Bacteria and culture conditions}

A. calcoaceticus and S. maltophilia were isolated from a DWDS in Braga (Portugal) and identified by 16S rRNA gene sequencing as described previously by Simões et al. (2007a).

Bacterial cells were grown overnight using a synthetic nutrient medium (glucose $5 \mathrm{~g} / \mathrm{L}$, peptone $2.5 \mathrm{~g} / \mathrm{L}$, yeast extract $1.25 \mathrm{~g} / \mathrm{L}$ and $0.2 \mathrm{M}$ phosphate buffer at pH 7) (Simões et al., 2009) at room temperature $\left(23 \pm 3{ }^{\circ} \mathrm{C}\right)$ and under agitation $(120 \mathrm{rpm})$ in an orbital incubator (New Brunswick Scientific, I26, USA). All growth medium compounds were purchased from Merck (VWR, Portugal). Cells were harvested by centrifugation (Eppendorf centrifuge 5810R) at $3777 \mathrm{~g}, 12 \mathrm{~min}$, washed twice with $0.2 \mathrm{M}$ phosphate buffered saline (PBS) at $\mathrm{pH} 7$ and resuspended in the same buffer or appropriated medium in order to achieve the bacterial concentration required for further experiments.

\subsection{Minimum inhibitory concentration of $\mathrm{NaOCl}$}

The minimum inhibitory concentration (MIC) of sodium hypochlorite $\mathrm{NaOCl}$ (Sigma, Sintra, Portugal) for A. calcoaceticus and S. maltophilia was determined by the broth microdilution method according to McBain et al. (2004). A pre-culture grown as described previously was used as inoculum $\left(\approx 10^{8} \mathrm{CFU} / \mathrm{mL}\right)$. MIC was determined in polystyrene 96 well microtiter plates (Orange Scientific, Belgium). $\mathrm{NaOCl}$ was prepared at diverse concentrations $(0.1-5000 \mathrm{mg} / \mathrm{L})$ from a $10 \%(\mathrm{v} / \mathrm{v})$ stock solution. A volume of $20 \mu \mathrm{L}$ of each $\mathrm{NaOCl}$ solution was added to each well containing $180 \mu \mathrm{L}$ of cell culture in synthetic nutrient medium. The optical density was measured in a microtiter plate reader at $610 \mathrm{~nm}$ (SpectraMax M2E, Molecular Devices) before and after $24 \mathrm{~h}$ incubation at room temperature $\left(23 \pm 3{ }^{\circ} \mathrm{C}\right)$ and $120 \mathrm{rpm}$. The MIC corresponds to the lowest concentration of $\mathrm{NaOCl}$ at which no growth was found. Each condition was tested in triplicate with three independent experiments.

\subsection{Substratum for bacterial adhesion and biofilm formation}

PVC coupons $(1 \times 1 \mathrm{~cm})$ were used as adhesion substratum. PVC was selected as a representative pipe material from DW networks (Simões et al., 2007a). In order to prepare PVC for further analysis, this material was immersed in a solution of commercial detergent (Sonasol Pril, Henkel Ibérica S. A.) in ultrapure water for $30 \mathrm{~min}$. The coupons were rinsed in ultrapure water and subsequently immersed in ethanol at $96 \%(\mathrm{v} / \mathrm{v})$ for $1 \mathrm{~min}$ in order to remove any remaining detergent (Simões et al., 2007a). Afterwards they were rinsed three times with ultrapure water and dried at $65^{\circ} \mathrm{C}$ for $3 \mathrm{~h}$, before being used for contact angle measurements, zeta potential assessment, adhesion and biofilm assays.

\subsection{The effect of $\mathrm{NaOCl}$ on bacterial surface charge - zeta potential measurement}

The zeta potential of PVC and bacteria, before and after contact with $\mathrm{NaOCl}$ ( $0.5 \mathrm{mg} / \mathrm{L}$ and MIC for S. maltophilia and A. calcoaceticus) 
for $30 \mathrm{~min}$, was determined using a Nano Zetasizer (Malvern Instruments, UK), according to Ferreira et al. (2011). The bacterial cultures were prepared as described previously. Afterwards, they were washed twice and resuspended in sterile distillated water to a final concentration of $10^{8} \mathrm{CFU} / \mathrm{mL}$. Bacterial suspensions without $\mathrm{NaOCl}$ were used as control. Each condition was tested in triplicate with three independent experiments.

\subsection{The effect of $\mathrm{NaOCl}$ on physicochemical properties of bacterial membranes - contact angle measurements}

Bacterial lawns were prepared for contact angle measurements as described by Busscher et al. (1984). The bacterial suspensions were exposed to $\mathrm{NaOCl}$ at $0.5 \mathrm{mg} / \mathrm{L}$ and at MIC of each bacterium for $30 \mathrm{~min}$ before contact angle measurements. The surface tension of the bacterial surfaces (with and without $\mathrm{NaOCl}$ exposure) and substratum were determined using the sessile drop contact angle method according to Simões et al. (2010a). The measurements were carried out at room temperature $\left(23 \pm 3{ }^{\circ} \mathrm{C}\right.$ ) using three different liquids: water, $\alpha$-bromonaphthalene and formamide (Sigma). Determination of contact angles was performed automatically using a model OCA 15 Plus (DataPhysics, Germany) video based optical contact angle measure instrument, allowing image acquisition and data analysis. Contact angle measurements, at least 20 determinations, of each liquid were performed for the selected bacteria and for PVC. The reference liquids surface tension components were obtained from literature (Janczuk et al., 1993).

\subsection{Determination of hydrophobicity and surface tension parameters}

The surface hydrophobicity and the surface tension parameters of bacteria and PVC surfaces were assessed after contact angle measurements according to the procedure described by Simões et al. (2007a). Bacteria and PVC hydrophobicities were assessed using the approach of van Oss et al. (1987, 1988, 1989). In this approach, the degree of hydrophobicity of a given material (i) is expressed as the free energy of interaction between two entities of that material when immersed in water $(\mathrm{w})-\Delta \mathrm{G}_{\mathrm{iwi}}$. If the interaction between the two entities is stronger than the interaction of each entity with water, $\Delta \mathrm{G}_{\mathrm{iwi}}^{\mathrm{TOT}}<0 \mathrm{~mJ} / \mathrm{m}^{2}$, it means that the material is hydrophobic. If $\Delta \mathrm{G}_{\mathrm{iwi}}^{\mathrm{TOT}}>0 \mathrm{~mJ} / \mathrm{m}^{2}$ the material is considered hydrophilic. $\Delta \mathrm{G}_{\mathrm{iwi}}$ can be calculated through the surface tension components of interacting entities according to Eq. 1:

$\Delta \mathrm{G}_{\mathrm{iwi}}^{\mathrm{TOT}}=-2\left(\sqrt{ } \gamma_{i}^{L w}-\sqrt{ } \gamma_{w}^{L w}\right)^{2}+4\left(\sqrt{\gamma_{i}^{+} \gamma_{w}^{-}}+\sqrt{\gamma_{i}^{-} \gamma_{w}^{+}}-\sqrt{\gamma_{i}^{+} \gamma_{i}^{-}}-\sqrt{\gamma_{w}^{+} \gamma_{w}^{-}}\right)$

where,

$$
\begin{aligned}
& \gamma^{\mathrm{LW}} \text { is the Lifshitz-van der Waals component of the surface free } \\
& \text { energy; } \\
& \gamma^{+} \text {represents the electron acceptor parameter; } \\
& \gamma^{-} \text {represents the electron donor parameter; } \\
& \gamma^{A B} \text { is the Lewis acid-base component, with } \gamma^{A B}=2 \times \sqrt{\gamma^{+} \gamma^{-}} \text {. }
\end{aligned}
$$

The surface tension components of bacteria and PVC were obtained by measuring the contact angle of the referred three pure liquids with well-known surface tension components and by simultaneous resolution of three equations of the form of Eq. 2.

$$
(1+\cos \theta) \gamma_{i}^{T O T}=2\left(\sqrt{\gamma_{s}^{L w} \gamma_{i}^{L w}}+\sqrt{\gamma_{s}^{+} \gamma_{i}^{-}}+\sqrt{\gamma_{s}^{-} \gamma_{i}^{+}}\right)
$$

where $\theta$ is the contact angle and $\gamma^{T O T}=\gamma^{L W}+\gamma^{A B}$.

\subsection{The effect of $\mathrm{NaOCl}$ on bacterial motility}

Overnight cultures grown in Luria-Bertani broth (LBB) (Merck, Portugal) were used to characterize bacterial motility. Fifteen microliters of these cultures were applied in the center of plates containing $1 \%$ tryptone (Merck), $0.25 \% \mathrm{NaCl}$ (Merck) and $0.3 \%, 0.7 \%$ or $1.5 \%(\mathrm{w} / \mathrm{v})$ agar (Merck) for swimming/colony spreading, swarming and twitching motilities, respectively (Butler et al., 2010; Stickland et al., 2010). The use of different concentrations of agar enables the characterization of different types of bacterial motility, once the medium porosity is directly related to the concentration of agar. $\mathrm{NaOCl}$ were incorporated into the medium obtaining the final concentrations of $0.5 \mathrm{mg} / \mathrm{L}$ and MIC, in order to determine if these concentrations affect bacterial motility. Then, the plates (with and without $\mathrm{NaOCl}$ ) were incubated at $23 \pm 3{ }^{\circ} \mathrm{C}$ and the diameter $(\mathrm{mm})$ of motility halos was accurately measured at 24,48 and $72 \mathrm{~h}$. Each condition was tested in triplicate with two independent cultures.

\subsection{Monolayer bacterial adhesion on PVC surfaces}

Adhesion tests were performed with A. calcoaceticus, S. maltophilia, and their co-culture, using PVC as adhesion surface. Also, the effect of $\mathrm{NaOCl}$ on the control of adhered cells was studied. PVC coupons with $1 \mathrm{~cm} \times 1 \mathrm{~cm}$, prepared as described previously, were inserted in 48-wells microtiter plates (Nunc, Denmark) and $1.2 \mathrm{~mL}$ of each cell suspension $\left(10^{8} \mathrm{CFU} / \mathrm{mL}\right.$ in PBS) was added to each well. In order to test adhesion of $A$. calcoaceticus-S. maltophilia co-culture, $600 \mu \mathrm{L}$ of each bacterial suspension. Monolayer adhesion on PVC coupons was allowed to occur for $2 \mathrm{~h}$ at $23 \pm 3^{\circ} \mathrm{C}$ in an orbital incubator at $120 \mathrm{rpm}$ according to Simões et al. (2007a). Negative controls were obtained by placing the PVC coupons in PBS without bacterial cells.

\subsection{Biofilm formation on PVC surfaces}

Biofilms were formed with A. calcoaceticus, S. maltophilia and their co-culture using PVC as substratum. Cell suspensions, PVC coupons and microtiter plate inoculation were prepared as described previously for cell adhesion assay. Biofilm formation was allowed to occur for $24 \mathrm{~h}$ at $23 \pm 3{ }^{\circ} \mathrm{C}, 120 \mathrm{rpm}$. Negative controls were obtained by placing the PVC coupons in diluted medium without bacterial cells.

\subsection{Effects of $\mathrm{NaOCl}$ on sessile bacteria culturability and removal}

PVC coupons with adhered cells and biofilms were exposed to $\mathrm{NaOCl}$ at $0.5 \mathrm{mg} / \mathrm{L}$ and at MIC for $30 \mathrm{~min}$. Co-culture adhered cells and dualspecies biofilms were exposed to the higher MIC. After biocide exposure, coupons were washed with sodium thiosulphate at $0.5 \%(\mathrm{w} / \mathrm{v})$ to quench the activity of $\mathrm{NaOCl}$ and then with $\mathrm{PBS}$ to remove nonadherent and weakly adherent bacteria according to Simões et al. (2010b). Afterwards, the number of cells attached to PVC was assessed by 4',6-diamidino-2-phenylindole (DAPI, Sigma) staining. Coupons with monolayer adhered bacteria were directly stained with $400 \mu \mathrm{L}$ of DAPI at $0.5 \mu \mathrm{g} / \mathrm{mL}$ for $10 \mathrm{~min}$ in the dark according to Simões et al. (2007b). Biofilms were scraped from the surfaces and resuspended in PBS. These biofilm suspensions, after vigorous vortexing for $1 \mathrm{~min}$ (optimized time to ensure the disruption of biofilm aggregates without compromising bacterial viability, allowing further counts of individual cells), were filtered $(0.5 \mathrm{~mL})$ using a $0.22 \mu \mathrm{m}$ black polycarbonate membrane (Nucleopore, UK). The membrane with bacteria was observed by epifluorescence microscopy after staining with $400 \mu \mathrm{L}$ of DAPI at $0.5 \mu \mathrm{g} / \mathrm{mL}$. Then, cells were visualized under an epifluorescence microscope Leica DM LB2 (Leica Microsystems, Germany) equipped with a filter sensitive to DAPI fluorescence ( $359 \mathrm{~nm}$ excitation filter in combination with a $461 \mathrm{~nm}$ emission filter). Twenty micrographs per coupon were obtained using a microscope camera (AxioCam HRC, Carl Zeiss) in order to calculate the number of cells per $\mathrm{cm}^{2}$. For dual species biofilms 
Table 1

Zeta potential values to A. calcoaceticus and S. maltophilia after exposure to different concentrations of $\mathrm{NaOCl}$ for $30 \mathrm{~min}$. The MIC are $125 \mathrm{mg} / \mathrm{L}$ for $A$. calcoaceticus and $175 \mathrm{mg} / \mathrm{L}$ for S. maltophilia.

\begin{tabular}{lll}
\hline $\begin{array}{l}{[\mathrm{NaOCl}]} \\
(\mathrm{mg} / \mathrm{L})\end{array}$ & \multicolumn{2}{c}{ Zeta potential $(\mathrm{mV})$} \\
\cline { 2 - 3 } & A. calcoaceticus & S. maltophilia \\
\hline 0 & $-28.0 \pm 0.6$ & $-30.7 \pm 1.4$ \\
0.5 & $-24.0 \pm 1.1$ & $-20.5 \pm 0.7$ \\
$\mathrm{MIC}$ & $-22.0 \pm 0.4$ & $-14.6 \pm 1.4$ \\
\hline
\end{tabular}

the number of cells per $\mathrm{cm}^{2}$ was counted for each bacterium. This was possible because these bacteria (in the same growth phase) had clear distinct shapes and sizes when observed under the microscope.

For culturability assessment, bacteria (monolayer adhered bacteria and biofilms) were scraped from the surfaces, resuspended in PBS and spread on Plate Count Agar (PCA, MercK, VWR) for colony forming units (CFU) enumeration. In order to break up biofilm clusters, bacterial suspensions were vortexed for $1 \mathrm{~min}$. The numbers of CFU were assessed after $24 \mathrm{~h}$ incubation at $23 \pm 3{ }^{\circ} \mathrm{C}$. Final results are presented as $\log \mathrm{CFU}$ per $\mathrm{cm}^{2}$ of adhesion surface. All the experiments were performed in triplicate with three repeats.

\subsection{Statistical analysis}

The data were analyzed using the statistical program SPSS version 20.0 (Statistical Package for the Social Sciences). Results were analyzed using One-Way ANOVA test. Statistical calculations were based on a confidence level $\geq 95 \%$ ( $P<0.05$ was considered statistically significant).

\section{Results}

\subsection{Minimum inhibitory concentration of $\mathrm{NaOCl}$}

Chlorine is commonly used as disinfectant in DWDS. The residual concentrations kept along the DWDS are essential to guarantee DW is microbiologically safe. Chlorine as $\mathrm{NaOCl}$ was used as an antimicrobial agent during this study. The MIC for each bacterium was assessed in order to understand the antimicrobial activity of $\mathrm{NaOCl}$. Complete growth inhibition occurred with $\mathrm{NaOCl}$ at $125 \mathrm{mg} / \mathrm{L}$ and $175 \mathrm{mg} / \mathrm{L}$ for A. calcoaceticus and S. maltophilia, respectively. These concentrations in addition to a residual concentration of $0.5 \mathrm{mg} / \mathrm{L}$ were used to assess the effects of $\mathrm{NaOCl}$ on bacterial surface physicochemical properties (surface charge, tension and hydrophobicity), on bacterial motility, and on the control of monolayer adhered bacteria and biofilms.

\subsection{Physicochemical characteristics and charge of bacterial surfaces and $P V C$}

The surface charge and hydrophobicity of bacteria and the substratum are important aspects that can influence the adhesion process, i.e. the first interaction between the bacterium and the substratum. Table 1 shows the surface charge of A. calcoaceticus and S. maltophilia in the absence/presence of $\mathrm{NaOCl}$. Both bacteria have the surface negatively charged, while PVC surface has positive charge $(11.3 \pm 0.6 \mathrm{mV})$. The exposure to increasing concentrations of $\mathrm{NaOCl}$ decreased the negativity of the bacterial surface charge. This effect was more significant for $S$. maltophilia than for A. calcoaceticus $(P<0.05)$. Concerning to surface tension and hydrophobicity, A. calcoaceticus and S. maltophilia had both hydrophilic surface properties $\left(\Delta \mathrm{G}_{\mathrm{iwi}}^{\mathrm{TOT}}>0 \mathrm{~mJ} / \mathrm{m}^{2}\right)$ with similar values $(P>0.05)$ of surface tension parameters (Table 2$)$. The PVC surface had also hydrophilic characteristics $\left(\Delta \mathrm{G}_{\mathrm{iwi}}^{\mathrm{TOT}}=55.9 \mathrm{~mJ} / \mathrm{m}^{2}\right)$ and did not have ability to accept electrons $\left({ }^{+}=0 \mathrm{~mJ} / \mathrm{m}^{2}\right)$. The exposure to $\mathrm{NaOCl}$ changed the hydrophobic characteristics of the bacterial surfaces. The $\Delta \mathrm{G}_{\mathrm{iwi}}^{\mathrm{TOT}}$ of $A$. calcoaceticus increased significantly $(P<0.05)$ after exposure to increasing concentrations of $\mathrm{NaOCl}$ from $17.7 \pm 2.8 \mathrm{~mJ} / \mathrm{m}^{2}$ (without treatment) to $29.4 \pm 4.0 \mathrm{~mJ} / \mathrm{m}^{2}(0.5 \mathrm{mg} / \mathrm{L}$ $\mathrm{NaOCl}$ ) and $72.7 \pm 9.0 \mathrm{~mJ} / \mathrm{m}^{2}$ (at $125 \mathrm{mg} / \mathrm{L}$ ). Also, the electron donor parameter $\left(^{-}\right.$) of A. calcoaceticus increased with the use of $\mathrm{NaOCl}$ at MIC (from $44.4 \pm 2.1$ to $77.1 \pm 7.8 \mathrm{~mJ} / \mathrm{m}^{2}$ ). The electron acceptor parameter $\left({ }^{+}\right)$suffered an opposite effect, decreasing with the residual biocide concentration (from $5.2 \pm 0.8 \mathrm{~mJ} / \mathrm{m}^{2}$ to $1.6 \pm 0.4 \mathrm{~mJ} / \mathrm{m}^{2}$ ), and losing all its ability to accept electrons $\left(0 \mathrm{~mJ} / \mathrm{m}^{2}\right)$ with $\mathrm{NaOCl}$ at $125 \mathrm{mg} / \mathrm{L}$. The exposure to $\mathrm{NaOCl}$ at 0.5 and $175 \mathrm{mg} / \mathrm{L}$ did not cause significant changes in S. maltophilia hydrophobicity and electron donor values $(P>0.05)$. The electron acceptor parameter decreased moderately $(P<0.05)$ after exposure to both $\mathrm{NaOCl}$ concentrations.

\subsection{The effect $\mathrm{NaOCl}$ on motility of A. calcoaceticus and S. maltophilia}

A. calcoaceticus and S. maltophilia showed the three studied forms of motility: swimming, swarming and twitching motility (Table 3). The increasing concentrations of $\mathrm{NaOCl}$ caused changes in A. calcoaceticus swimming and twitching motilities. Swimming motility (after $72 \mathrm{~h}$ ) of A. calcoaceticus decreased $(P<0.05)$ when exposed to $\mathrm{NaOCl}$ at MIC. Also, the twitching motility was reduced due to $\mathrm{NaOCl}(P<0.05)$, when analyzed at $72 \mathrm{~h}$. A. calcoaceticus swarming motility was not significantly affected by $\mathrm{NaOCl}(P>0.05)$. S. maltophilia motilities were not affected by $\mathrm{NaOCl}$, regardless the concentration used.

\subsection{The effect of $\mathrm{NaOCl}$ on culturability and removal of monolayer adhered bacteria}

The results on the effects of $\mathrm{NaOCl}$ on the removal of monolayer adhered bacteria are presented in Fig. 1. A. calcoaceticus and S. maltophilia single species and co-culture adhered on PVC at similar extents $(P>0.05)$. In the co-culture $S$. maltophilia was predominant compared to the numbers of $A$. calcoaceticus $(P<0.05)$. The use of $\mathrm{NaOCl}$ at a residual concentration did not cause bacterial removal for any of the conditions tested $(P>0.05)$. However, the MIC caused modest removal $(P<0.05)$. S. maltophilia (maximum removal of $0.69 \mathrm{log}$ ) and A. calcoaceticus (maximum removal of $0.89 \mathrm{log}$ ) monolayer adhered cells demonstrated close susceptibilities to $\mathrm{NaOCl}(P>0.05)$. The bacteria in co-culture were even less susceptible to $\mathrm{NaOCl}$. In fact, no significant reduction of A. calcoaceticus and S. maltophilia in co-culture was observed.

Table 2

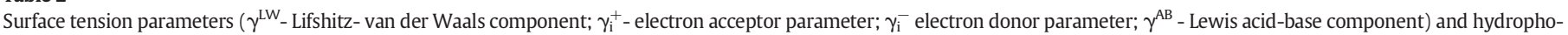
bicity $\left(\Delta \mathrm{G}_{\mathrm{iwi}}^{\mathrm{TOT}}\right)$ of $A$. calcoaceticus and S. maltophilia after exposure to different concentrations of NaOCl for $30 \mathrm{~min}$.

\begin{tabular}{|c|c|c|c|c|c|c|}
\hline \multirow[t]{2}{*}{ Bacteria } & \multirow[t]{2}{*}[\mathrm{NaOCl}]{$(\mathrm{mg} / \mathrm{l})$} & \multicolumn{4}{|c|}{ Surface tension parameters $\left(\mathrm{mJ} / \mathrm{m}^{2}\right)$} & \multirow{2}{*}{$\frac{\text { Hydrophobicity }\left(\mathrm{m} J / \mathrm{m}^{2}\right)}{\Delta \mathrm{G}_{\mathrm{iwi}}^{\mathrm{TOT}}}$} \\
\hline & & $\gamma^{\mathrm{LW}}$ & $\gamma_{i}^{+}$ & $\gamma_{\mathrm{i}}^{-}$ & $\gamma^{\mathrm{AB}}$ & \\
\hline \multirow[t]{3}{*}{ A. calcoaceticus } & 0 & $25.6 \pm 0.9$ & $5.2 \pm 0.8$ & $44.4 \pm 2.1$ & $30.1 \pm 1.8$ & $17.7 \pm 2.8$ \\
\hline & 0.5 & $35.9 \pm 1.3$ & $1.6 \pm 0.4$ & $52.2 \pm 3.1$ & $18.4 \pm 1.7$ & $29.4 \pm 4.0$ \\
\hline & 125 & $33.3 \pm 1.5$ & $0.0 \pm 0.0$ & $77.1 \pm 7.8$ & $0.0 \pm 0.0$ & $72.7 \pm 9.0$ \\
\hline \multirow[t]{3}{*}{ S. maltophilia } & 0 & $29.8 \pm 5.2$ & $5.4 \pm 1.3$ & $53.3 \pm 2.3$ & $29.2 \pm 6.2$ & $27.1 \pm 5.4$ \\
\hline & 0.5 & $36.4 \pm 1.2$ & $1.1 \pm 0.8$ & $47.7 \pm 7.3$ & $15.5 \pm 3.4$ & $29.2 \pm 6.4$ \\
\hline & 175 & $31.0 \pm 1.1$ & $1.8 \pm 0.4$ & $49.5 \pm 3.6$ & $19.7 \pm 2.7$ & $27.1 \pm 5.4$ \\
\hline
\end{tabular}


Table 3

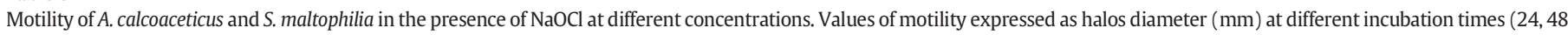
and $72 \mathrm{~h}$ ).

\begin{tabular}{|c|c|c|c|c|c|c|c|c|c|}
\hline \multicolumn{10}{|c|}{ A. calcoaceticus } \\
\hline$[\mathrm{NaOCl}](\mathrm{mg} / \mathrm{L})$ & \multicolumn{3}{|c|}{0} & \multicolumn{3}{|c|}{0.5} & \multicolumn{3}{|c|}{125} \\
\hline Time (h) & 24 & 48 & 72 & 24 & 48 & 72 & 24 & 48 & 72 \\
\hline Swimming (mm) & $0.0 \pm 0.0$ & $10 \pm 3$ & $52.0 \pm 3.0$ & $1.0 \pm 0.0$ & $18.0 \pm 6.9$ & $45.0 \pm 3.5$ & $2.7 \pm 0.5$ & $4.5 \pm 0.7$ & $10.0 \pm 4.0$ \\
\hline Swarming (mm) & $2.0 \pm 0.0$ & $2.3 \pm 0.6$ & $3.3 \pm 0.6$ & $1.5 \pm 0.7$ & $2.3 \pm 1.2$ & $3.0 \pm 1.0$ & $3.3 \pm 1.5$ & $3.0 \pm 1.0$ & $3.2 \pm 1.2$ \\
\hline Twitching (mm) & $3.0 \pm 0.0$ & $6.5 \pm 0.7$ & $6.7 \pm 0.6$ & $2.0 \pm 0.0$ & $2.7 \pm 0.6$ & $3.0 \pm 1.0$ & $2.0 \pm 0.0$ & $3.0 \pm 1.0$ & $3.3 \pm 0.6$ \\
\hline \multicolumn{10}{|c|}{ S. maltophilia } \\
\hline$[\mathrm{NaOCl}](\mathrm{mg} / \mathrm{L})$ & \multicolumn{3}{|c|}{0} & \multicolumn{3}{|c|}{0.5} & \multicolumn{3}{|c|}{175} \\
\hline Time $(\mathrm{h})$ & 24 & 48 & 72 & 24 & 48 & 72 & 24 & 48 & 72 \\
\hline Swimming (mm) & $3.0 \pm 1.0$ & $10.3 \pm 2.3$ & $20.6 \pm 1.5$ & $2.3 \pm 0.6$ & $8.0 \pm 1.0$ & $18.6 \pm 1.5$ & $4.6 \pm 1.5$ & $12.3 \pm 0.6$ & $20.3 \pm 2.9$ \\
\hline Swarming (mm) & $2.7 \pm 1.5$ & $5.6 \pm 1.2$ & $7.0 \pm 2.0$ & $3.3 \pm 1.5$ & $5.3 \pm 1.5$ & $7.3 \pm 2.4$ & $2.0 \pm 1.4$ & $3.5 \pm 0.7$ & $5.0 \pm 1.4$ \\
\hline Twitching (mm) & $2.3 \pm 1.2$ & $4.0 \pm 0.0$ & $4.3 \pm 1.0$ & $2.3 \pm 0.6$ & $3.3 \pm 0.6$ & $4.3 \pm 0.6$ & $3.3 \pm 0.6$ & $4.3 \pm 0.6$ & $5.0 \pm 1.0$ \\
\hline
\end{tabular}

The results on the effects of $\mathrm{NaOCl}$ on $\mathrm{CFU}$ numbers of monolayer adhered bacteria are presented in Fig. 2. The number of $A$. calcoaceticus CFU was lower than for $S$. maltophilia in both single species and cocultures adhered on PVC $(P<0.05)$. The use of $\mathrm{NaOCl}$ at $0.5 \mathrm{mg} / \mathrm{L}$ and at MIC caused total CFU reduction for all the conditions tested.

\subsection{The effect of $\mathrm{NaOCl}$ on biofilm culturability and removal}

The $24 \mathrm{~h}$-old biofilms were exposed to $\mathrm{NaOCl}$ at $0.5 \mathrm{mg} / \mathrm{L}$ and at MIC for $30 \mathrm{~min}$ (Fig. 3). Both bacteria formed single and dual-species biofilms with similar cell densities $(P>0.05)$. Their exposure to $0.5 \mathrm{mg} / \mathrm{L} \mathrm{NaOCl}$ did not cause significant removal of single and dualspecies biofilms from PVC $(P>0.05)$. NaOCl at MIC caused modest biofilm removal $(P<0.05)$. S. maltophilia biofilms were the least susceptible with removal of $0.54 \log$ while $A$. calcoaceticus biofilm removal was 0.88 log. In dual species biofilms, $1.05 \mathrm{log}$ and $0.92 \mathrm{log}$ removal was observed for A. calcoaceticus and S. maltophilia, respectively.

The results on the effects of $\mathrm{NaOCl}$ on CFU numbers of biofilms are presented in Fig. 4. S. maltophilia had higher number of CFU on PVC than A. calcoaceticus in both single and dual-species biofilms $(P<0.05) . \mathrm{NaOCl}$ at $0.5 \mathrm{mg} / \mathrm{L}$ caused significant $\mathrm{CFU}$ reduction of A. calcoaceticus biofilms: $3.9 \log \mathrm{CFU} / \mathrm{cm}^{2}$ for single species and $1.8 \log \mathrm{CFU} / \mathrm{cm}^{2}$ for dual-species biofilms. S. maltophilia CFU reduction on single species was around $2.1 \log \mathrm{CFU} / \mathrm{cm}^{2}$ and $1.4 \log \mathrm{CFU} / \mathrm{cm}^{2}$ for dual-species biofilms. Therefore, CFU reduction of dual-species biofilms was lower than for single species biofilms. Treatment with $\mathrm{NaOCl}$ at MIC caused complete CFU reduction of both bacteria in single and dualspecies biofilms $(P>0.05)$.

\section{Discussion}

The presence of biofilms in DWDS is a public health concern due to their potential to harbor pathogenic microorganisms (Li et al., 2016). Therefore, it is important to understand biofilm formation ability of DW microorganisms and their behavior to control strategies. In this study, two opportunistic microorganisms isolated from a DWDS, A. calcoaceticus and S. maltophilia, were characterized in terms of surface charge, tension parameters and hydrophobicity, before and after exposure to $\mathrm{NaOCl}$. Similarly to other studies, microtiter plates were used as model system for adhesion and biofilm formation under laboratorial conditions (Johansen et al., 2009; Pompilio et al., 2008; Simões et al., 2010a, 2010b). In fact, microtiter plates are commonly used as the standard bioreactor system for adhesion and biofilm formation of bacteria isolated from many different environments, providing reliable comparative data (Andersson et al., 2008; Djordjevic et al., 2002; Simões et al., 2010a; Suraju et al., 2015).

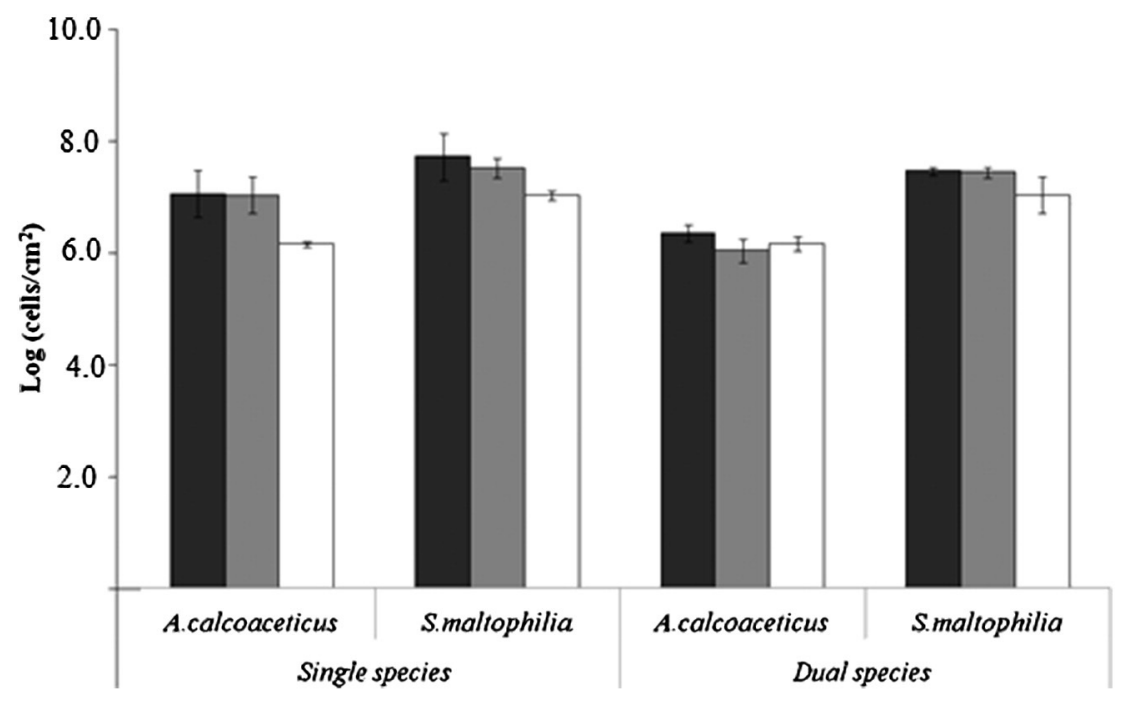

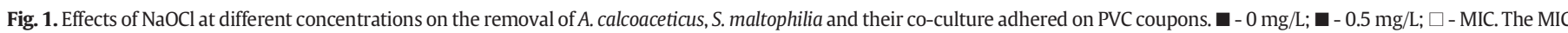
are $125 \mathrm{mg} / \mathrm{L}$ for $A$. calcoaceticus and $175 \mathrm{mg} / \mathrm{L}$ for $S$. maltophilia. Co-cultures were exposed to $175 \mathrm{mg} / \mathrm{L}$. 


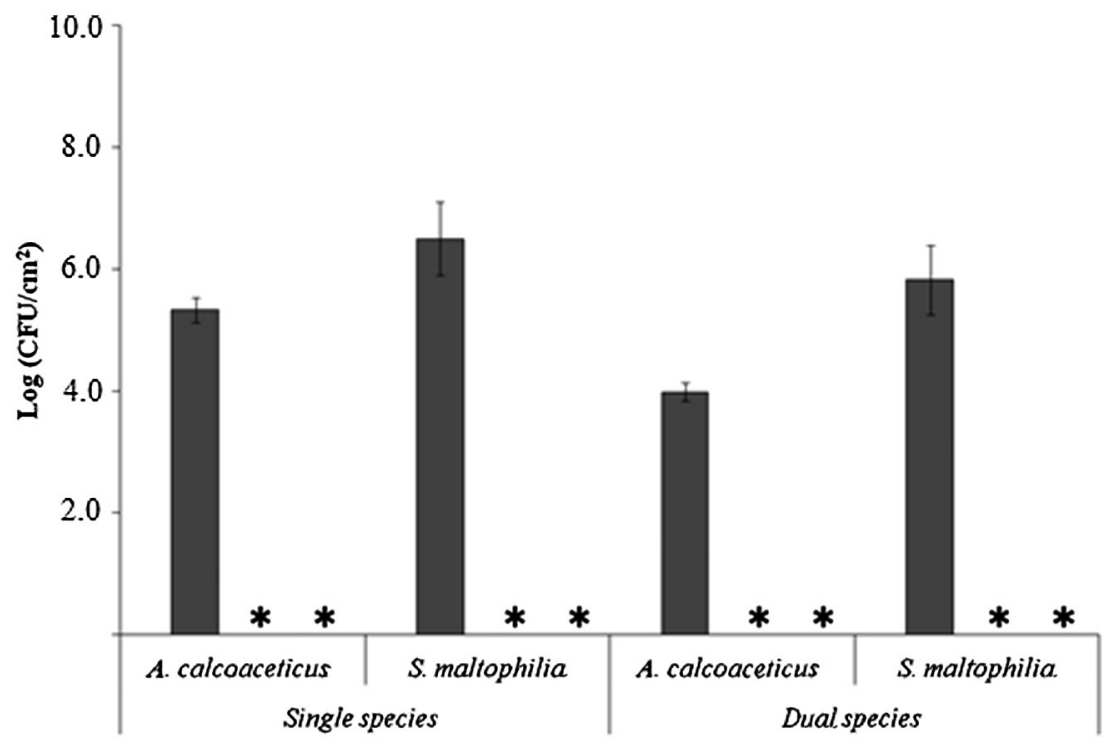

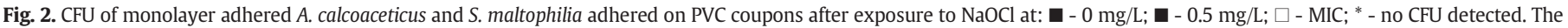
detection limit is $2.75 \log \mathrm{CFU} / \mathrm{cm}^{2}$. The MIC are $125 \mathrm{ppm}$ for A. calcoaceticus and $175 \mathrm{ppm}$ for $S$. maltophilia. Co-cultures were exposed to $175 \mathrm{mg} / \mathrm{L}$.

According to the MIC values A. calcoaceticus was more susceptible to $\mathrm{NaOCl}$ than S. maltophilia. MIC in the range $100-500 \mathrm{ppm}$ were also described by DeQueiroz (2004) for diverse Gram-negative bacteria. Jaglic et al. (2012) found MIC of $\mathrm{NaOCl}$ against diverse Gram-negative and -positive bacteria in the range 1000-4000 ppm. In another study, Seier-Petersen et al. (2014) described MIC of 5000 ppm against Bacillus subtilis. The differences in the MIC between the diverse studies is apparently due to the distinct susceptibility of the bacteria but also on the method used to determine MIC, particularly the growth medium. Those growth medium with high organic matter content will require higher $\mathrm{NaOCl}$ concentrations to exert antimicrobial effects due to the interaction between the medium constituents and the disinfectant. $\mathrm{NaOCl}$ in water exhibits a chemical dynamic balance: $\mathrm{NaOCl}+\mathrm{H}_{2} \mathrm{O} \leftrightarrow \mathrm{NaOH}+\mathrm{HOCl} \leftrightarrow \mathrm{Na}^{+}+\mathrm{OH}^{-}+\mathrm{H}^{+}+\mathrm{OCl}^{-}$. NaOCl destroys microorganisms by chlorinating the lipid protein substance in the bacterial cell wall to form toxic chloro compounds and induces the leakage of macromolecules from the cells (Kim et al., 2008). Moreover $\mathrm{NaOH}$ can neutralize amino acids forming water and salt. Hypochlorous acid $(\mathrm{HOCl})$ when interacting with protein amino groups forms chloramines. Chloramination reaction between chlorine and the amino group forms chloramines that interfere with the cell metabolism (Estrela et al., 2002). $\mathrm{HOCl}$ and hypochlorite ions $\left(\left(\mathrm{OCl}^{-}\right)\right)$cause the oxidation of some amino acids, namely the sulfhydryl groups or sulfide bridges, present in proteins (Pattison et al., 2007; Rosen et al., 2009). Moreover, they interact strongly with bacterial membranes causing the oxidation of outer membrane proteins and facilitating the oxidation of inner cell proteins with subsequent cell death (Arana et al., 1999). In this study, the effects of $\mathrm{NaOCl}$ against planktonic and sessile A. calcoaceticus and S. maltophilia was tested at $0.5 \mathrm{ppm}$, a recommended level of free chlorine to keep along the DWDS (WHO, 2011), and at MIC.

Both bacteria had the surface negatively charged possibly due to the presence of anionic carboxyl and phosphate groups in the membrane surface (Ahimou et al., 2002). Similar values of zeta potential were described by other authors for strains of A. calcoaceticus and S. maltophilia. van der Mei et al. (1991) found that the surface charge of A. calcoaceticus RAG1 and A. calcoaceticus MR-481 was $-20 \mathrm{mV}$ and $-33 \mathrm{mV}$, respectively; van Merode et al. (2007) assessed zeta

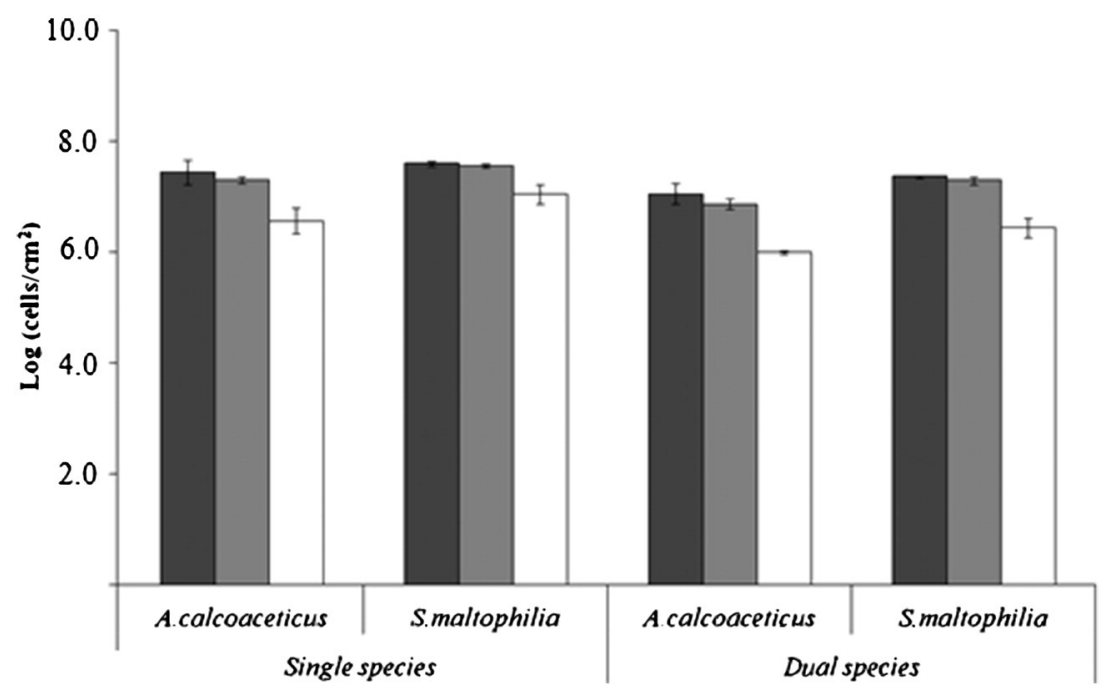

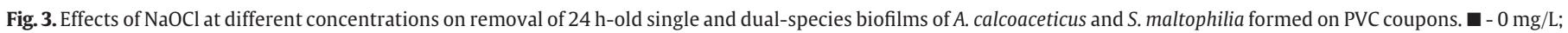
- $0.5 \mathrm{mg} / \mathrm{L}$; $\square$ - MIC. The MIC are $125 \mathrm{ppm}$ for A. calcoaceticus and $175 \mathrm{ppm}$ for S. maltophilia. Dual-species biofilms were exposed to $175 \mathrm{mg} / \mathrm{L}$. 


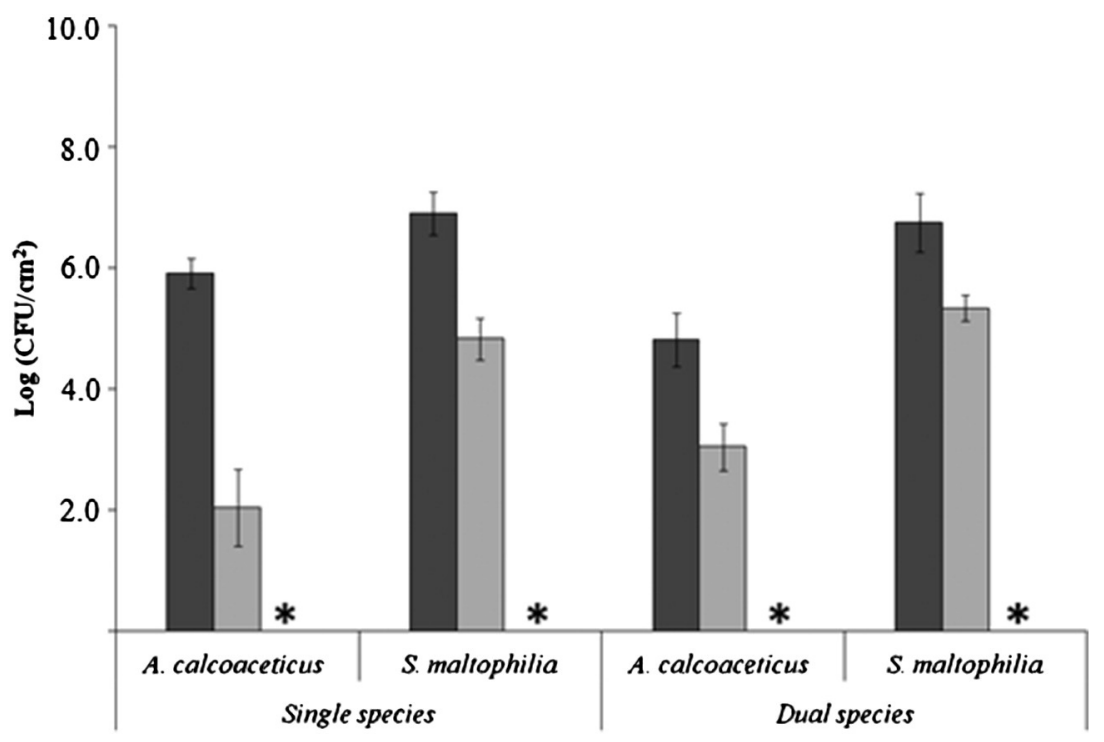

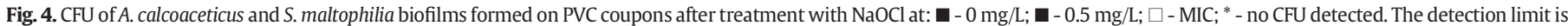
$2.75 \log \mathrm{CFU} / \mathrm{cm}^{2}$. The MIC are $125 \mathrm{ppm}$ for A. calcoaceticus and $175 \mathrm{ppm}$ for S. maltophilia. Dual-species biofilms were exposed to $175 \mathrm{mg} / \mathrm{L}$.

potential values for $S$. maltophilia in the range of $-14 \pm 1$ and $-24 \pm 1 \mathrm{mV}$. As the selected bacteria and PVC had opposite charges it is expected that no electrostatic repulsion will affect the adhesion process. The application of $\mathrm{NaOCl}$ changed bacterial surface charge to less negative values. This result proposes that if the bacteria in planktonic state are exposed to $\mathrm{NaOCl}$ their ability to adhere on PVC will possibly decrease due to lower electrostatic effects. In fact, $\mathrm{NaOCl}$ caused significant changes on the surface charge of both bacteria, particularly of S. maltophilia. The formation of $\mathrm{HOCl}$ when $\mathrm{NaOCl}$ is mixed with water can cause the loss of electrons on the bacterial membrane and consequently alter the surface charge (Peck et al., 2011).

Hydrophobicity is an important property on bacterial attachment but also is essential to ensure the ability of the metabolites to transit through the membrane (Moorman et al., 2008). Bacterial hydrophobicity can be altered by changes in fatty acid and protein composition that occur in response to stress conditions. Changes in fatty acid composition of membrane lipids are the most important reaction of bacteria against membrane active substances (Murínová and Dercová, 2014). Both A. calcoaceticus and S. maltophilia showed to be hydrophilic as was also reported by Simões et al. (2007a, 2010a). However, the use of $\mathrm{NaOCl}$ decreased the hydrophobicity of $A$. calcoaceticus, possibly due to the oxidation and chlorination of membrane unsaturated fatty acids as proposed by Fukayama et al. (1986). The oxidation and chlorination of cell surface molecules could help to explain the changes in the surface tension parameters, particularly the reduction of the electron donor parameter and the increase of the electron acceptor. These results also demonstrate that surface physicochemical surface properties of $A$. calcoaceticus were affected in a higher extent than those of S. maltophilia. Bacterial motility is also an important feature that contributes to the adhesion process, helping the microorganism reaching the most favorable environment and to gain advantage when competing with other microorganisms in response to external conditions (Fenchel, 2002; Maes et al., 2013; Stocker et al., 2008). Cell motility is characterized by the presence of structures like flagella, pili or fimbriae that play an important role in microbial initial adhesion to a surface and consequent biofilm formation. These structures are able to overcome the repulsive forces associated with the substratum and can contribute to the overall surface hydrophobicity (Donlan, 2002; Mandlik et al., 2008; O'Toole and Kolter, 1998). Several types of bacterial motility were already defined such as swimming, swarming, gliding, sliding and twitching (Kearns, 2010). In this work swimming, swarming and twitching motility were studied. These types of motility were already described for A. calcoaceticus and S. maltophilia. Hentuchsen and Blom (1975) found that A. calcoaceticus is able to move through twitching motility, while the tests done by Simões et al. (2007c) described also that this bacteria is able to move through swimming motility. Pompilio et al. (2008) showed that most of S. maltophilia tested strains are able to move by swimming and twitching motilities, but concluded that these characteristics may not be very influent on initial adhesion but are crucial on biofilm development (Pompilio et al., 2011). Ferrer-Navarro et al. (2013) studied the motility of four strains of S. maltophilia and all the strains presented swimming, swarming and twitching motility. Bacterial exposure to $\mathrm{NaOCl}$ only affected A. calcoaceticus motility, reducing swimming motility which means that the biocide can affect in some way the ability of $A$. calcoaceticus to get closer to the surface and to overcome repulsive forces (Donlan, 2002). Previous studies also described changes in bacterial motility caused by the exposure to some disinfectants. Majtán and Majtánová (2002) described a reduction of Pseudomonas aeruginosa motility when exposed to several quaternary ammonium compounds. GarcíaHeredia et al. (2013) observed a reduction of swarming motility of diverse Salmonella spp. strains after treatment with a citrus-based disinfectant. However, to our knowledge no studies exist on the effects of $\mathrm{NaOCl}$ on bacterial motility.

Both A. calcoaceticus and S. maltophilia (single and co-culture) adhered on PVC at similar extents as assessed by DAPI staining. Nevertheless, the numbers of CFU of $S$. maltophilia were significantly higher than those of A. calcoaceticus in both single and dual-species monolayer adhered cells and biofilms. This difference is arguably related to the limitations of the plate count method (Simões et al., 2005). The underestimation of viable cell can be caused by several reasons, as the presence of starved or injured cells or potentially viable but nonculturable cells, the inadequate culture conditions and the aggregation of bacteria that can lead to the formation of one colony from more than one cell, thereby underestimating the total number of cells (Banning et al., 2002). Nevertheless, in order to avoid the aggregation effect, bacterial suspensions were vortexed for $1 \mathrm{~min}$. The comparison between DAPI and CFU results also reinforce that removal and killing of sessile cells are distinct phenomena. In fact, $\mathrm{NaOCl}$ was able to cause total CFU reduction (total CFU reduction was achieved with $\mathrm{NaOCl}$ at $\mathrm{MIC}$ for all tested conditions) and quite poor removal effects. S. maltophilia was more resistant than A. calcoaceticus. However, their co-culture increased resilience to 
$\mathrm{NaOCl}$. Schwering et al. (2013) also found that chlorine tolerance of pathogenic bacteria increased when they were associated in a multispecies sessile community.

After the adhesion process bacteria begin producing EPS to form mature biofilms. These extracellular substances are recognized as biocide quenching agents increasing substantially biofilm resistance to antimicrobials (Vu et al., 2009). In this study the effects of $\mathrm{NaOCl}$ was assessed on the control of $24 \mathrm{~h}$-old biofilms. Both bacteria showed similar ability to form biofilm, with the number of $A$. calcoaceticus in biofilm being similar to those of $S$. maltophilia. The number of culturable A. calcoaceticus was lower than those of S. maltophilia, as happened in the adhesion assay. A. calcoaceticus formed biofilms more susceptible to $\mathrm{NaOCl}$ than those of S. maltophilia. However, biofilm removal from $\mathrm{NaOCl}$ exposure was low for all the conditions. Lenz et al. (2010) reported no CFU on a model DW biofilm after application of diverse disinfectants (free chlorine-electrochemically activated, chlorine dioxide, hydrogen peroxide, silver and fruit acids). However, biofilm remain adhered on the surface. de Souza et al. (2014) also found that $\mathrm{NaOCl}$ at $250 \mathrm{mg} / \mathrm{L}$ was ineffective on the removal of Staphylococcus aureus from food contact surfaces. Davison et al. (2010) tested the efficacy of chlorine at $10 \mathrm{mg} / \mathrm{L}$ and $50 \mathrm{mg} / \mathrm{L}$ on Staphylococcus epidermidis biofilms treatment and found low reduction. Biofilms were more resistant than monolayer adhered cells as evidenced by CFU results, even if $\mathrm{NaOCl}$ at a residual concentration was able to cause significant CFU reduction. Further studies were performed with A. calcoaceticus-S. maltophilia dual-species biofilms in order to ascertain the role of species association in biofilm susceptibility to $\mathrm{NaOCl}$. It was observed a lower $\mathrm{CFU}$ reduction of dual-species biofilms compared to those single species. Species association did not affect the biofilm removal from PVC compared to the single species scenario, demonstrating the resistance and resilience of both single and dual biofilms to removal, even if $\mathrm{NaOCl}$ at $\mathrm{MIC}$ caused total CFU reduction for all the tested conditions. The biofilm remaining after antimicrobial treatment is of particular concern due to the potential on the colonizing microorganisms to reseed the biofilm (Gagnon et al., 2005; Simões et al., 2009). Moreover, the results on dual-species biofilm removal are intriguing as previous studies report the increased resistance of multispecies biofilms when compared to their single species counterparts (Behnke et al., 2011; Behnke and Camper, 2012; Burmølle et al., 2006; Simões et al., 2009, 2010a). In fact, comparing with the experiments of monolayer adhered bacteria it was expected that the presence of EPS and other biofilm features will increase even more the resistance of dual-species biofilms.

\section{Conclusions}

The overall results demonstrate that $\mathrm{NaOCl}$ interact strongly with A. calcoaceticus increasing their cell surface charge, hydrophilicity and electron donor properties. Also, it caused reduction of $A$. calcoaceticus swimming and twitching motilities. S. maltophilia was affected by $\mathrm{NaOCl}$ exposure in a lower extent: the MIC was higher than for A. calcoaceticus and the disinfectant only increased the cell membrane electron donor properties and the surface charge to less negative values. No effects of $\mathrm{NaOCl}$ under residual levels and at the MIC were found on S. maltophilia motility. The disinfectant had low effects on the removal of monolayer adhered A. calcoaceticus and S. maltophilia (single species and co-culture) and their biofilms. However, even at a residual concentration $\mathrm{NaOCl}$ caused total reduction of monolayer adhered CFU and significant reduction of biofilm CFU. S. maltophilia sessile cells were invariably more resistant to removal and killing than A. calcoaceticus. This clearly proposes the need for new methods to monitor the microbiological status of a DWDS, considering that biofilms represent $95 \%$ of the overall biomass in a DWDS, while only $5 \%$ is in the water phase (Flemming et al., 2002). Moreover, alternative and/or complementary methods to $\mathrm{NaOCl}$ are required for an effective and environmentally friendly DW disinfection (Meireles et al., 2016). This knowledge on the distinct susceptibilities and behavior of microorganisms can contribute to the design of effective control strategies, able to control the key microorganisms, such as S. maltophilia, in the resistance and resilience of a biofilm that will guarantee safe and high-quality drinking water.

\section{Acknowledgements}

This work was financially supported by: Project POCI-01-0145FEDER-006939 (Laboratory for Process Engineering, Environment, Biotechnology and Energy - LEPABE funded by FEDER funds through COMPETE2020 - Programa Operacional Competitividade e Internacionalização (POCI) - and by national funds through FCT Fundação para a Ciência e a Tecnologia/MEC: Project POMACEAInn-INDIGO/0001/2014, SFRH/BD/103810/2014 and SFRH/BPD/ $81982 / 2011$.

\section{References}

Ahimou, F., Denis, F.A., Touhami, A., Dufrêne, Y.F., 2002. Probing microbial cell surface charges by atomic force microscopy. Langmuir 18, 9937-9941.

Andersson, S, Rajarao, G.K. Land, C.J. Dalhammar, G., 2008. Biofilm formation and interactions of bacterial strains found in wastewater treatment systems. FEMS Microbiol. Lett. 283, 83-90.

Arana, I., Santorum, P., Muela, A., Barcina, I., 1999. Chlorination and ozonation of wastewater: comparative analysis of efficacy through the effect on Escherichia coli membranes. J. Appl. Microbiol. 86, 883.

Banning, N., Toze, S., Mee, B.J., 2002. Escherichia coli survival in groundwater and effluent measured using a combination of propidium iodide and the green fluorescent protein. J. Appl. Microbiol. 93, 69-76.

Behnke, S., Camper, A.K., 2012. Chlorine dioxide disinfection of single and dual species biofilms, detached biofilm and planktonic cells. Biofouling 28, 635-647.

Behnke, S., Parker, A.E., Woodall, D., Camper, A.K., 2011. Comparing the chlorine disinfection of detached biofilm clusters with those of sessile biofilms and planktonic cells in single- and dual-species cultures. Appl. Environ. Microbiol. 77, 7176-7184.

Brooke, J.S., 2012. Stenotrophomonas maltophilia: an emerging global opportunistic pathogen. Clin. Microbiol. Rev. 25, 2-41.

Burmølle, M., Webb, J.S., Rao, D., Hansen, L.H., Sørensen, S.J., Kjelleberg, S., 2006. Enhanced biofilm formation and increased resistance to antimicrobial agents and bacterial invasion are caused by synergistic interactions in multispecies biofilms. Appl. Environ. Microbiol. 72, 3916-3923.

Busscher, H.J., Weerkamp, A.H., van der Mei, H.C., van Pelt, A.W., de Jong, H.P., Arends, J., 1984. Measurement of the surface free energy of bacterial cell surfaces and its relevance for adhesion. Appl. Environ. Microbiol. 48, 980-983.

Butler, M.T., Wang, Q., Harshey, R.M., 2010. Cell density and mobility protect swarming bacteria against antibiotics. Proc. Natl. Acad. Sci. U. S. A. 107, 3776-3781.

Cervia, J.S., Ortolano, G.A., Canonica, F.P., 2008. Hospital tap water as a source of Stenotrophomonas maltophilia infection. Clin. Infect. Dis. 46, 1485-1487.

Davison, W.M., Pitts, B., Stewart, P.S., 2010. Spatial and temporal patterns of biocide action against Staphylococcus epidermidis biofilms. Antimicrob. Agents Chemother. 54, 2920-2927.

de Souza, E.L., Meira, Q.G.S., de Medeiros, Barbosa I., Athayde, A.J.A.A., da Conceição, M.L., de Siqueira Júnior, J.P., 2014. Biofilm formation by Staphylococcus aureus from food contact surfaces in a meat-based broth and sensitivity to sanitizers. Braz. J. Microbiol. 45, 67-75.

Denton, M., Kerr, K.G., 1998. Microbiological and clinical aspects of infection associated with Stenotrophomonas maltophilia. Clin. Microbiol. Rev. 11, 57-80.

DeQueiroz, G., 2004. A new broad spectrum disinfectant suitable for the food industry. Louisiana State University, Department of Food Science PhD Thesis.

Djordjevic, D., Wiedmann, M., McLandsborough, L.A., 2002. Microtiter plate assay for assessment of Listeria monocytogenes biofilm formation. Appl. Environ. Microbiol. 68, 2950-2958.

Donlan, R., 2002. Biofilms: microbial life on surfaces. Emerg. Infect. Dis. 8, 881-890.

Doyle, R.J., 2000. Contribution of the hydrophobic effect to microbial infection. Microbes Infect. 2002 (2), 391-400.

Estrela, C., Estrela, C.R.A., Barbin, E.L., Spano, J.C.E., Carchesan, M.A., Pécora, J.D., 2002. Mechanisms of action of sodium hypochlorite. Braz. Dent. J. 13, 113-117.

Fenchel, T. 2002. Microbial behavior in a heterogeneous world. Science 296, 1068-1071.

Ferreira, C., Pereira, A.M., Pereira, M.C., Melo, L.F., Simões, M., 2011. Physiological changes induced by the quaternary ammonium compound benzyldimethyldodecylammonium chloride on Pseudomonas fluorescens. J. Antimicrob. Chemother. 66, 1036-1043.

Ferrer-Navarro, M., Planell, R., Yero, D., Mongiardini, E., Torrent, G., Huedo, P., Martínez, P., Roher, N., Mackenzie, S., Gibert, I., et al., 2013. Abundance of the quorum-sensing factor Ax21 in four strains of Stenotrophomonas maltophilia correlates with mortality rate in a new zebrafish model of infection. PLoS One 8, e67207.

Flemming, H.-C., Percival, S., Walker, J., 2002. Contamination potential of biofilms in water distribution systems. Water Sci. Technol. 2, 271-280.

Fukayama, M., Tan, H., Wheeler, W., Wei, C., 1986. Reactions of aqueous chlorine and chlorine dioxide with model food compounds. Environ. Health Perspect. 69, 267-274.

Gagnon, G.A., Rand, J.L., O'leary, K.C., Rygel, A.C., Chauret, C., Andrews, R.C., 2005. Disinfectant efficacy of chlorite and chlorine dioxide in drinking water biofilms. Water Res. 39, 1809-1817. 
Gales, A.C., Jones, R.N., Forward, K.R., Liñares, J., Sader, H.S., Verhoef, J., 2001. Emerging importance of multidrug-resistant Acinetobacter species and Stenotrophomonas maltophilia as pathogens in seriously ill patients: geographic patterns, epidemiological features, and trends in the SENTRY antimicrobial surveillance program (1997-1999). Clin. Infect. Dis. 32, S104-S113.

García-Heredia, A., Orue, N., García, S., 2013. Efficacy of commercial citrus-based disinfectants to inhibit growth, swarming, and biofilm formation of Salmonella and decontaminate parsley. J. Food Agric. Environ. 11, 1295-1299.

Garrett, T.R., Bhakoo, M., Zhang, Z., 2008. Bacterial adhesion and biofilms on surfaces. Prog. Nat. Sci. 18, 1049-1056.

Hentuchsen, J., Blom, J., 1975. Correlation between twitching motility and possession of polar fimbriae in Acinetobacter calcoaceticus. Acta Pathol. Microbiol. Scand. B 83B, 103-115.

Jaglic, Z., Červinková, D., Vlková, H., Michu, E., Kunová, G., Babák, V., 2012. Bacterial biofilms resist oxidising agents due to the presence of organic matter. Czech J. Food Sci. 30, 178-187.

Janczuk, B., Chibowski, E., Bruque, J.M., Kerkeb, M.L., Caballero, F.G., 1993. On the consistency of surface free energy components as calculated from contact angles of different liquids: an application to the cholesterol surface. J. Colloid Interface Sci. 159, 421-428.

Johansen, T.B., Agdestein, A., Olsen, I., Nilsen, S.F., Holstad, G., Djønne, B., 2009. Biofilm formation by Mycobacterium avium isolates originating from humans, swine and birds. BMC Microbiol. 9, 159.

Kearns, D.B., 2010. A field guide to bacterial swarming motility. Nat. Rev. Microbiol. 8, 634-644.

Kerr, C.J., Osborn, K.S., RObson, G.D., Handley, P.S., 1998. The relationship between pipe material and biofilm formation in laboratory model system. J. Appl. Microbiol. 85 (Suppl. 1), 29S-38S.

Kim, J., Pitts, B., Stewart, P.S., Camper, A., Yoon, 2008. Comparison of the antimicrobial effects of chlorine, silver ion and tobramycin on biofilm. Antimicrob. Agents Chemother. 52, 1446-1453.

Lenz, J., Linke, S., Gemein, S., Exner, M., Gebel, J., 2010. Verification of the efficacy of chemical disinfection and sanitation measures in in-building distribution systems. Int. J. Hyg. Environ. Health 213, 198-203.

Li, W., Wang, F., Zhang, J., Qiao, Y., Xu, C., Liu, Y., Qian, L., Li, W., Dong, B., 2016. Community shift of biofilms developed in a full-scale drinking water distribution system switching from different water sources. Sci. Total Environ. 544, 499-506.

Maes, A., Gracia, C., Bréchemier, D., Hamman, P., Chatre, E., Lemelle, L., Bertin, P.N., Hajnsdorf, E., 2013. Role of polyadenylation in regulation of the flagella cascade and motility in Escherichia coli. Biochimie 95, 410-418.

Majtán, V., Majtánová, L., 2002. Influence of subinhibitory concentrations of disinfectants on hydrophobicity, alginate production, and motility of Pseudomonas aeruginosa. Chem. Pap. 56, 345-350.

Mandlik, A., Swierczynski, A., Das, A., Ton-That, H., 2008. Pili in Gram-positive bacteria: assembly, involvement in colonization and biofilm development. Trends Microbiol. $16,33-40$.

McBain, A.J., Ledder, R.G., Sreenivasan, P., Gilbert, P., 2004. Selection for high-level resistance by chronic triclosan exposure is not universal. J. Antimicrob. Chemother. 53, 772-777.

Meireles, A., Giaouris, E., Simões, M., 2016. Alternative disinfection methods to chlorine for use in the fresh-cut industry. Food Res. Int. 82, 71-85.

Moorman, M.A., Thelemann, C.A., Zhou, S., Pestka, J.J., Linz, J.E., Ryser, E.T., 2008. Altered hydrophobicity and membrane composition in stress-adapted Listeria innocua. J. Food Prot. 71, 182-185.

Murínová, S., Dercová, K., 2014. Response mechanisms of bacterial degraders to environmental contaminants on the level of cell walls and cytoplasmic membrane. Int. J. Microbiol. 16.

Narciso-da-Rocha, C., Vaz-Moreira, I., Svensson-Stadler, L., Moore, E.B., Manaia, C., 2013. Diversity and antibiotic resistance of Acinetobacter spp. in water from the source to the tap. Appl. Microbiol. Biotechnol. 97, 329-340.

Niquette, P., Servais, P., Savoir, R., 2000. Impacts of pipe materials on densities of fixed bacterial biomass in a drinking water distribution system. Water Res. 34, 1952-1956.

O'Toole, G.A., Kolter, R., 1998. Flagellar and twitching motility are necessary for Pseudomonas aeruginosa biofilm development. Mol. Microbiol. 30, 295-304.

Pal, R.B., Kale, V.V., 1981. Acinetobacter calcoaceticus-an opportunistic pathogen. J. Postgrad. Med. 27, 218-221.

Pattison, D.I., Hawkins, C.L., Davies, M.J., 2007. Hypochlorous acid-mediated protein oxidation: how important are chloramine transfer reactions and protein tertiary structure? Biochemistry 46, 9853-9864.

Peck, B., Workeneh, B., Kadikoy, H., Patel, S.J., Abdellatif, A., 2011. Spectrum of sodium hypochlorite toxicity in man-also a concern for nephrologists. NDT Plus 4, 231-235.

Penna, T.C.V., Mazzola, P.G., Martins, A.M.S., 2001. The efficacy of chemical agents in cleaning and disinfection programms. BMC Infect. Dis. 1, 16.

Percival, S.L., Walker, J.T., 1999. Potable water and biofilms: a review of the public health implications. Biofouling 14, 99-115.

Pompilio, A., Piccolomini, R., Picciani, C., D'Antonio, D., Savini, V., Di Bonaventura, G., 2008. Factors associated with adherence to and biofilm formation on polystyrene by Stenotrophomonas maltophilia: the role of cell surface hydrophobicity and motility. FEMS Microbiol. Lett. 287, 41-47.

Pompilio, A., Pomponio, S., Crocetta, V., Gherardi, G., Verginelli, F., Fiscarelli, E., Dicuonzo, G., Savini, V., D'Antonio, D., Di Bonaventura, G., 2011. Phenotypic and genotypic characterization of Stenotrophomonas maltophilia isolates from patients with cystic fibrosis: genome diversity, biofilm formation, and virulence. BMC Microbiol. 11, 1-17.

Rosen, H., Klebanoff, S.J., Wang, Y., Brot, N., Heinecke, J.W., Fu, X., 2009. Methionine oxidation contributes to bacterial killing by the myeloperoxidase system of neutrophils. Proc. Natl. Acad. Sci. U. S. A. 106, 18686-18691.

Rożej, A., Cydzik-Kwiatkowska, A., Kowalska, B., Kowalski, D., 2015. Structure and microbial diversity of biofilms on different pipe materials of a model drinking water distribution systems. World J. Microbiol. Biotechnol. 31, 37-47.

Safe Drinking Water Committee, Board on Toxicology and Environment Health Hazards National Research Council, 1982i. Drinking water and health. vol. 4. National Academic Press, Washington DC, p. 62 (ISBN:0-309-55424-1).

Schwering, M., Song, J., Louie, M., Turner, R.J., Ceri, H., 2013. Multi-species biofilms defined from drinking water microorganisms provide increased protection against chlorine disinfection. Biofouling 29, 917-928.

Seier-Petersen, M.A., Jasni, A., Aarestrup, F.M., Vigre, H., Mullany, P., Roberts, A.P., Agers $\varnothing$, Y., 2014. Effect of subinhibitory concentrations of four commonly used biocides on the conjugative transfer of Tn916 in Bacillus subtilis. J. Antimicrob. Chemother. 69 343-348.

Simões, L.C., Simões, M., 2013. Biofilms in drinking water: problems and solutions. RSC Adv. 3, 2520-2533.

Simões, M., Pereira, M.O., Vieira, M.J., 2005. Validation of respirometry as a short-term method to assess the efficacy of biocides. Biofouling 21, 9-17.

Simões, L.C., Azevedo, N., Pacheco, A., Keevil, C.W., Vieira, M.J., 2006. Drinking water biofilm assessment of total and culturable bacteria under different operating conditions. Biofouling 22, 91-99.

Simões, L.C., Simões, M., Oliveira, R., Vieira, M.J., 2007a. Potential of the adhesion of bacteria isolated from drinking water to materials. J. Basic Microbiol. 47, 174-183.

Simões, M., Pereira, M.O., Sillankorva, S., Azeredo, J., Vieira, M.J., 2007b. The effect of hydrodynamic conditions on the phenotype of Pseudomonas fluorescens biofilms. Biofouling 23, 249-258.

Simões, L.C., Simões, M., Vieira, M.J., 2007c. Biofilm interactions between distinct bacterial genera isolated from drinking water. Appl. Environ. Microbiol. 73, 6192-6200.

Simões, M., Simões, L.C., Vieira, M.J., 2009. Species association increases biofilm resistance to chemical and mechanical treatments. Water Res. 43, 229-237.

Simões, L.C., Simões, M., Vieira, M., 2010a. Adhesion and biofilm formation on polystyrene by drinking water-isolated bacteria. Anton. Leeuw. J. Microbiol. 98, 317-329.

Simões, L.C., Simões, M., Vieira, M.J., 2010b. Influence of the diversity of bacterial isolates from drinking water on resistance of biofilms to disinfection. Appl. Environ. Microbiol. 76, 6673-6679.

Stickland, H.G., Davenport, P.W., Lilley, K.S., Griffin, J.L., Welch, M., 2010. Mutation of nfxB causes global changes in the physiology and metabolism of Pseudomonas aeruginosa. J. Proteome Res. 9, 2957-2967.

Stocker, R., Seymour, J.R., Samadani, A., Hunt, D.E., Polz, M.F., 2008. Rapid chemotactic response enables marine bacteria to exploit ephemeral microscale nutrient patches. Proc. Natl. Acad. Sci. U. S. A. 105, 4209-4214.

Sun, H., Shi, B., Bai, Y., Wang, D., 2014. Bacterial community of biofilms developed under different water supply conditions in a distribution system. Sci. Total Environ. 472, 99-107.

Suraju, M.O., Barnes, S.L., Sanamvenkata, S., Esmaeli, M., Shishodia, S., Rosenzweig, J.Á., 2015. The effects of indoor and outdoor dust exposure on the growth, sensitivity to oxidative stress, and biofilm production of three opportunistic bacterial pathogens. Sci. Total Environ. 538, 949-958.

Talon, D., Bailly, P., Leprat, R., Godard, C., Deconnink, E., Cahn, J.Y., Michel-Briand, Y., 1994 Typing of hospital strains of Xanthomonas maltophilia by pulsed-field gel electrophoresis. J. Hosp. Infect. 27, 209-217.

Tsai, Y.-P., 2005. Simulation of biofilm formation at different assimilable organic carbon concentrations under lower flow velocity condition. J. Basic Microbiol. 45, 475-485.

van der Mei, H., Cowan, M., Busscher, H., 1991. Physicochemical and structural studies on Acinetobacter calcoaceticus RAG-1 and MR-481-two standard strains in hydrophobicity tests. Curr. Microbiol. 23, 337-341.

van Merode, A.E.J., Pothoven, D.C., Van Der Mei, H.C., Busscher, H.J., Krom, B.P., 2007. Surface charge influences enterococcal prevalence in mixed-species biofilms. J. Appl. Microbiol. 102, 1254-1260.

van Oss, C.J., Chaudhury, M.K., Good, R.J., 1987. Monopolar surfaces. Adv. Colloid Interface Sci. 28, 35-64.

van Oss, C.J., Good, R.J., Chaudhury, M.K., 1988. Additive and nonadditive surface tension components and the interpretation of contact angles. Langmuir 4, 884-891.

van Oss, C.J., Ju, L., Chaudhury, M.K., Good, R.J., 1989. Estimation of the polar parameters of the surface tension of liquids by contact angle measurements on gels. J. Colloid Interface Sci. 128, 313-319.

Vincenti, S., Quaranta, G., De Meo, C., Bruno, S., Ficarra, M.G., Carovillano, S., Ricciardi, W. Laurenti, P., 2014. Non-fermentative gram-negative bacteria in hospital tap water for haemodialysis and bronchoscope flushing: prevalence and distribution of antibiotic resistant strains. Sci. Total Environ. 499, 47-54.

Vu, B., Chen, M., Crawford, R., Ivanova, E., 2009. Bacterial extracellular polysaccharides involved in biofilm formation. Molecules 14, 2535-2554.

Weber, D.J., Rutala, W.A., Blanchet, C.N., Jordan, M., Gergen, M.F., 1999. Faucet aerators: a source of patient colonization with Stenotrophomonas maltophilia. Am. J. Infect. Control 27, 59-63.

WHO, 2011. Guidelines for drinking Water quality. fourth ed. World Health Organization. 